\title{
Genealogies of the Study of Material Texts
}

\author{
The French Trajectory
}

Roger Chartier

\begin{abstract}
This essay is devoted to the different branches of the French material textual tree. Analytical bibliography was not one of them. The decisive elements were the attention paid by H.-J. Martin to the lay-out of the texts as a fundamental source for the history of reading, the reception of McKenzie's sociology of texts and motto "forms effect meaning", and the appropriation of Petrucci's association between morphological description and social history of the written objects.
\end{abstract}

\begin{abstract}
A t the beginning was the Coming of the Book. Published in 1958, this book designed by Lucien Febvre (who died in the previous year) and almost entirely written by Henri-Jean Martin defined the new territory of the "histoire du livre". ${ }^{1}$ Its main topics were the geography of printing, the book trade, and the social condition of printers, booksellers, and binders. The "materiality of the texts" is never considered as such. This absence is perhaps the consequence of the radical separation established between the two natures of the book studied in the first seven chapters as a commodity, "une marchandise", and, in the last chapter, as a "ferment", a force of change. The body and the soul of the book that were intimately associated in the old metaphor of the book described as human creature were thus radically divorced.

Two reasons, however, make it necessary to place this book at the origin of our French genealogy. The first one is the implicit tension between Febvre and Martin over the definition of the book itself. For Lucien Febvre, who accepted without any reluctance the title chosen by Henri Berr for this volume of the series "L'Evolution de l'Humanité", the book is "coming"
\end{abstract}

1. This work was translated into English by David Gerard; see Febvre and MarTIN 1976 [1990]. 
with Gutenberg. For him, the book is the printed book. In his preface, he affirmed that the book is a "nouveau venu au sein des sociétés occidentales; le Livre, qui a commencé sa carrière au milieu du XVe siècle" ["a newcomer in western society. It began its career in the mid-15th century"] $(1958,12)$. Consequently, the purpose of the volume, as it was defined by Febvre, must be "étudier ici l'action culturelle et l'influence du livre pendant les trois cents premières années de son existence" ["to examine the influence and practical significance of the book ("le livre") during the first 300 years of its existence"] $(1958,14) .^{2}$ Henri-Jean Martin, who at the time of the writing of the volume was still a student at the Ecole des Chartes (the school that since 1821 trained future librarians and archivists) knew well that Gutenberg did not invent the book. He did not challenge directly Febvre's flamboyant statement, but he opened the book with an "Introduction" written by Marcel Thomas, curator of the Department of Manuscripts at the Bibliothèque Nationale, and devoted to "rappeler brièvement ce que fut dans le monde occidental le livre manuscrit qui, durant tant de siècles, fut l'unique instrument de diffusion de la pensée écrite" ["briefly recalling the historical role of the manuscript book ('le livre manuscrit'), for so many centuries the sole written medium through which ideas found expression"] $(1958,17)$. In 1976, the English translator David Gerard discreetly reinforced Martin's perspective. He softened some of Febvre's assertions: the book is a "relative newcomer" [the word "relative" is added] in the mid-fifteenth century and the purpose of the volume is "to examine the significance of the printed book during the first 300 years of its existence" [the word "printed" is added] (1976, 10, 11). He also gave to the book a subtitle absent in the French original edition: "The Impact of Printing 1450-1800".

Moreover, in several chapters, Henri-Jean Martin emphasized the continuities between manuscript books and printed ones. Such continuities are textual with the massive, printed reproduction of the juridical corpus, medieval chronicles, or chivalric novels, but they are also technical and material: "the advent of the printing press did not mean a sudden change in the appearance of the book. [. . . The printed book moved by degrees away from its original model, the manuscript" $(1976,78)$. The third chapter of the volume is dedicated to "The presentation of the book" and considers types and formats, colophons and title pages, page layout and illustrations. However, even if McKerrow's Introduction to Bibliography for Literary Students and an article by Pollard on woodcuts were mentioned in the bibliog-

2. Unless otherwise noted, the translations offered here in brackets are literal translations using the English but without the additions made by the translator. 
raphy, no reference to English or American New Bibliography is made in the chapter. It is thus without analytical bibliography that the materiality of the book (but not of the text) was introduced in The Coming of the Book and the French "histoire du livre".

The same was true when in the 1980s and 1990s Henri-Jean Martin became more and more interested in what he called the "mise en page" and "mise en texte". In two volumes published in 1990 and 2000, Martin stressed the importance of two fundamental transformations of the presentation of the texts (at least in France): the triumph of roman type over gothic letters in the 1530s and the introduction of blank spaces and paragraphs (first in philosophical texts) in the mid-seventeenth century. This second transformation was understood by Martin as an effect of the transformation of the conception of writing itself, when it was no more considered as a representation of oral discourse but as governed by its own logic.

From such a perspective, the layout of the texts became a fundamental document for the history of reading. In the preface of Histoire et pouvoirs de l'écrit, published in 1996, Martin made this point very explicitly. ${ }^{3}$ The aim of his book was "sasir dans quelle mesure la manière de presenter les textes a pu traduire ou orienter la logique et les modes de raisonnement de telle époque ou tel milieu" ["to understand how the modalities of the presentation of the texts were able to translate or to guide the logic and the modes of reasoning in a particular historical moment or for a particular social milieu" (my translation)] (1996, vii). The study of the modes of inscription of the texts on the page or in the book was thought of as a fundamental resource for the history of "reading" defined as appropriation and interpretation.

In the 1980s and 1990s, however, the French genealogy of the material text was no longer exclusively French and was opened to what we call now the "materiality of the text". A first reason for this change was the reception of D. F. McKenzie's Panizzi Lectures. Delivered in 1985, published by the British Library the following year, they were translated into French in 1991. It is as the sociology of text that analytical bibliography was introduced among French historians of the book. Particularly important was the sentence that became a motto: "forms effect meaning". It obliged historians of the book to consider the "expressive function" of all the non-verbal elements that constitute a book: format, characters, layout, punctuation. Followed by a partial translation of Margreta de Grazia and Peter Stally-

3. An English translation of the first (1988) edition of this work appears under the title The History and Power of Writing; see Martin 1994. The Preface is not in the 1988 edition and it is not present in the 1994 English translation. 
brass's seminal article "The Materiality of the Shakespearean Text" in the journal Genesis in 1995, McKenzie's work had a dual effect. ${ }^{4}$ On the one hand, it contributed to transforming the editing of the French "classiques", as illustrated by the new editions in La Pléiade of Racine and Molière's CEuvres, both more conscious than the previous editions of the importance of the typographic non-verbal elements (for example, punctuation). On the other hand, it led to a consideration of the dialectical relationship existing between the materiality of texts and their appropriation by their readers.

The material forms of the printed objects are responding to reading expectations, but, at the same time, they are framing readers' responses. As McKenzie wrote, "New readers make new texts, and their new meanings are a function of their new forms" $(1986,20)$. It is the reason why the materiality of the texts both "translates" and "guides" reading, according Martin's expressions. It is also the reason of frequent misquotations or even misprintings (as in Routledge's Book History Reader in 2006) of McKenzie's "forms effect meaning" transformed into "forms affect meaning" [emphases added]. Each formulation gives a different power to the forms of presentation of the texts: either they embody the meaning or they possibly alter it.

Another decisive branch in the French genealogy of the material text came from Italy. The reception of the work of Armando Petrucci, whose 1986 book La scrittura was translated into French in 1993, emphasized the morphological continuities existing between scribal and print cultures, either for the meaning attributed to the different formats of the book ("libro da banco" in-folio, Humanistic book in-quarto, libretti da mano in small formats) or for the uses of the different characters (gothic, roman, italics) that were all prior to the invention of Gutenberg. Devoted to the totality of the productions and practices that characterize an entire written culture, Petrucci's work introduces into the history of the book the materiality of manuscript texts. Petrucci focused attention on the multiple forms of writing (public or private, monumental or humble, scribal or printed) that paper rendered possible in European societies. As acknowledged recently by Peter Stallybrass, such attention echoed the overlooked first chapter of Febvre and Martin's book that considered the introduction of paper in Europe as a "question préalable", as a condition of possibility for the diffusion of the printing press. The fundamental distinction introduced by Petrucci between the power over writing (monopolized by the authorities, the dominant classes, and men) and the power of writing (progressively

4. For a partial translation of this essay into French, see de Grazia et StallyBRASs 1995b. 
acquired by women and popular classes) allowed him (and his readers) to closely associate morphological description with social history, to locate the materiality of each written object within the social conditions that governed its production, uses, and meanings. ${ }^{5}$ More recently the materiality of the texts became an essential element in editing practices as demonstrated, for example, by Francisco Rico's work devoted to the mutation of genre and meaning imposed on Lazarillo de Tormes, framed as a handwritten epistle but submitted to the conventions governing printed texts (chapters, woodcuts, marginal rubrics) in its first printed editions. ${ }^{6}$

French genealogy of the material text, opened to the appropriations of foreign traditions, leads to focus today on the various reasons that explain why the "same" work was published, circulated, and read in so many different texts. This distinction between the platonist and the pragmatic identity of the written works, as David Scott Kastan coined it, does not refer only to the mode of attribution of the texts (authorship and anonymity), to the textual variants introduced by authors, editors or compositors, or to translations between languages; rather, its first and fundamental determination resides in the multiple modalities of embodiment of the written word? Materiality matters and, indeed, forms effect meaning — and sometimes affect it.

Collège de France and University of Pennsylvania

\section{Works Cited}

de Grazia, Margreta and Peter Stallybrass. 1995a. "The Materiality of the Shakespearean Text". Shakespeare Quarterly 44.3: 255-83.

—. 1995b. "La matérialité du texte shakespearien", traduit par Delphine LemoNNier et François Laroque. Genesis 7: 9-27.

Febvre, Lucien et Henri-Jean Martin. 1958. L'Apparition du livre. (Bibliothèque de synthèse historique. L'Évolution de l'humanité, no. 49.) Paris: Albin Michel.

- 1976 [1990]. The Coming of the Book: The Impact of Printing 1450-1800, edited by Geoffrey Nowell-Smith and David Wootton; translated by David Gerard. London: N.L.B. (new edition: Verso).

Finkelstein, David and Alistair McCleery, eds. 2006. The Book History Reader. Abingdon-on-Thames: Routledge.

Kastan, David Scott. 2001. Shakespeare and the Book. Cambridge: Cambridge University Press.

5. See Petrucci 1988.

6. See Rico 1988 and Rico 2005.

7. See Kastan 2001, 117-18. 
Martin, Henri-Jean. 1988 [1996]. Histoire et pouvoirs de l'écrit. Paris: Librairie Académique Perrin (new edition: Albin Michel).

1990. Mise en page et mise en texte du livre manuscrit. Paris: Éditions du Cercle de la Librairie.

1994. The History and Power of Writing, translated by Lydia G. Cochrane. Chicago and London: The University of Chicago Press.

- 2000. Mise en page et mise en texte. La naissance du livre moderne (XIVe-XVIIe siècles). Paris: Éditions du Cercle de la Librairie.

McKenzie, D[onald] F. 1986 [1999]. Bibliography and the Sociology of Texts. London: The British Library (new edition: Cambridge University Press).

1991. La bibliographie et la sociologie des textes, traduit par Marc Amfreville, Préface de Roger Chartier. Paris: Éditions du Cercle de la Librairie.

Petrucci, Armando. 1986. La scrittura, Ideologia e rappresentazione. Rome: Einaudi. 1988. "Pouvoir de l'écriture, pouvoir sur l'écriture dans la Renaissance italienne". Annales. Économies, Sociétés, Civilisations 43.4: 823-47.

1993. Jeux de lettres. Formes et usages de l'inscription en Italie, 11e-20e siècles, traduit par Monique Aym ARd. Paris: Éditions de l'École des hautes études en sciences sociales.

Rico, Francisco. 1988. "La princeps del Lazarillo. Título, capitulación y epígrafes de un texto apócrifo”. In Problemas del Lazarillo, by Francisco Rico, 113-51. Madrid: Cátedra.

2005. El texto del "Quijote". Preliminares a una ecdótica del Siglo de Oro. Valladolid: Centro para la Edición de los Clásicos Españoles. 